\title{
Policies and Strategies for Increasing Revenue Region Sector Through Tax
}

\author{
Rya Rizqi Amalia ${ }^{1}$ and Lathifah Hanim ${ }^{2}$
}

Abstract. The problem of this research is what strategies do for Boosting Regional Income Tax By Sector as well as what are the constraints and solutions in practice the tax collection. The method used in this study is a sociological juridical approach, in this case the authors emphasize research aimed at obtaining legal knowledge empirically by going directly to the field to see the condition of the actual tax collection practices.

Based on the results of this study concluded that to streamline the management of taxes, some of the steps taken, among others, in addition to institutional changes also include improvements in the quality of human resources, with more technical personnel engage in structural and functional training. Meanwhile provided at taxpayer administer tax (especially payment) then checkouts cultivated close as possible to the location of taxes. Measures that have been done partly by making payments at BRI every district office, or can be deposited directly to the official tax collector. Obstacles encountered include the tax system is not maximized and necessary repairs, because it is still limited to the tax are estimated to have less control levels, whereas other tax sector is still using the old system (eg street lighting tax). The advice can be given in this study included the need for rigor in the implementation of tax legislation, this condition is manifested in the existence of a compromise in the tax collection system. In addition to the limited human resources, it is necessary to find a way out as soon as possible, whether fixed using existing human resources, cooperation with third parties in collecting taxes or empowering the village and district level personnel during the tax collection, especially for taxes routine. HR management is urgently needed, because given that if the tax levy can be optimally then tax receipts will always increase every year which will impact on the development of a local maximum.

Keywords: Taxes; Autonomous Region; Local Revenue.

\section{Introduction}

Revenue is the revenue from the tax sector revenue, retribution, the result of regional-owned enterprises, the results of separated areas of wealth management, and other authorized local revenue. ${ }^{3}$ Another opinion suggests that the PAD is all income derived from the original economic area. ${ }^{4}$ Pursuant to Article 1 paragraph 18 of Act No. 33 on the financial balance between central and local government, the PAD in definition as local earned income levied by local regulations in accordance with the legislation. Article 3 (1) stated that the PAD aims at providing authority to local

\footnotetext{
${ }^{1}$ Student of Master of Law, Universitas Islam Sultan Agung Semarang and Civil Servants, email rya_rizqi@yahoo.com

${ }^{2}$ Faculty of Law Unissula

${ }^{3}$ Mardiasmo 2002, "OtonomidanManajemenKeuangan Regions", Publisher ANDI, Yogyakarta, p. 132.

${ }^{4}$ Halim, Abdul, 20014, "ManajemenKeuangan Regions": EdisiRevisi 'UPP AMP YKPN Yogyakarta, p. 36.
} 
governments to fund the implementation of regional autonomy in accordance with the region's potential as an embodiment of Decentralization.

The main objective of decentralization policies on the one hand in order to support the national macro policies that are strategic and on the other hand with decentralization of government authority to the regions, the region will experience a significant management process than that of regional autonomy aims to:

- accelerate regional economic development and strong effective by empowering actors and the economic potential of the region.

- accelerate rural development in order to empower society, especially farmers and fishermen through infrastructure providers, building system agribusiness, small industry and handicrafts, institutional development, mastery of technology and utilization of natural resources.

- improving the quality of human resources in the area in accordance with the potential and regional interests through adequate education budget providers.

- promote development in all areas based on the principles of decentralization and regional autonomy.

Decentralization can be interpreted as recognition or delegation of authority public bodies higher to public bodies lower to independently and based on consideration of the interests of its own decision-making arrangements and governance and the structure of the authority held including the principles of the division of authority. ${ }^{5}$

Region is a potential source of revenue to contribute to the reception area. The definition of the tax itself is responsibility funding by persons or entities without direct payment of regional heads are balanced, which can be imposed by legislation in force, which is used to finance the implementation of local government and regional development. ${ }^{6}$

Principles the division of authority include:

- unitarisme and federalism,

- centralization and decentralization (in the narrow sense).

- concentration and deconcentration.

Unitarisme and federalism applies to federal States, where the federal government and the government of states to base the exercise of powers separate constitutions which together ensure a division of authority between the federal state and the state. Authority are not mutually supervise, but parallel to the restrictions of each other. Centralization and decentralization are used when concerned with the relations in the unitary state or in a state of a federation. Thus decentralized country if more powers and duties in the areas of policy implementation is delivered or assigned to public bodies that are not directly under the central government. While the concentration and deconcentration is a tendency to spread the functions of government at a certain level it extends to government organizations.

Further Ruiter explains that decentralizasion according to the general opinion is divided into two types:

- territorial decentralization, and

\footnotetext{
${ }^{5}$ Hoogerwerf, A, 1983, IlmuPemerintahan, Jakarta: Erland, p. 500.

${ }^{6}$ Yani, Ahmad, 2008, HubunganKeuanganantaraPemerintahPusatdan Regions in Indonesia, PT. King GrafindoPersada, Jakarta, p. 52.
} 
- Functional.

Territorial decentralization over of power to organize and manage their own household (autonomous) and limit such arrangements are local. While functional decentralization is the transfer of power to regulate and manage certain functions and limits of the said regulation is the type of the function itself, for example, for land, health, education and so on. ${ }^{7}$

To the authors wanted to know what are the strategies for enhancing local revenue?

\section{Research Methods}

The approach used in this study is a sociological juridical approach is to identify and conceptualize law as a social institution that is real and functional in real life system. In this case the authors emphasize research aimed at obtaining legal knowledge empirically by going directly to the field to see the condition of the actual tax collection practices.

\section{Discussion}

Any strategy should certainly be in line with the paradigm of development of a region, especially with regard to the regional budget is concerned. It is necessary to generate the local budget truly reflects the interests and expectations of the local community towards financial management economically, efficiently and effectively. Because that strategy to be implemented can see all things.

The strategy here will be focused on the strategy of increasing taxes, more particularly, to increase revenue Regency / City. The increase in the tax sector must be directed at efforts continuous and ongoing basis to the local revenues continue to increase, which in turn is expected to reduce dependence on revenues from government sources on it (the central government). In an effort to increase the tax essentially be achieved through intensification and extension efforts.

The paradigm of local budgets required in order to implement the strategy of increasing local revenues are:

- The regional budget should be based on the public interest;

- The regional budget has to be managed with good results and low cost;

- The regional budget should be able to give a rational transparency and accountability for the entire budget cycle;

- The regional budget has to be managed with performance approach to all types of expenditure and revenue;

- Local budgets should grow the professionalism of the work in any organization concerned;

- The regional budget should provide flexibility for the administrators to maximize the management of the fund on the principle of value for money. ${ }^{8}$

\footnotetext{
${ }^{7}$ Ibid, p. 3.

${ }^{8}$ Mardiasmo 2002, Autonomy and Local Financial Management, Publisher ANDI, Yogyakarta.
} 
Wealth management asset optimization strategy areas include:

- identification and inventory value and potential of regional assets;

- the area of asset management information system; (2) the area of asset management information system;

- supervision and control of the use of assets; and

- involvement of various professions or relevant expertise as an internal auditor and appraiser or assessor.

Intensification of local revenues is an action or efforts to increase acceptance by way of voting more rigorous, strict and meticulous. In a large dictionary Indonesian, intensification is defined as the subject of more intense activity increases. Therefore, the emphasis is more on development than the activities undertaken in empowering potential.

Extending the efforts to multiply the sources of local revenue that is new, but in an effort to extending this sourced from local taxes and levies must not conflict with the basic policies of national, namely taxes and levies, implemented not solely to explore the local revenue in the form of an adequate source of revenue, but also to implement other fiscal functions so as not to burden the people. Explicitly the possibility of extending the already regulated in Act No. 18 of 1997 on Regional Tax and Retribution area, which has been amended by Act No. 34 of 2000 .

In the Act it is emphasized that local regulations may set taxes Regency / City in addition to the stated in paragraph (2) of Act 34 of 2000, which specifies the following criteria Characteristically as a tax and not a levy;

- Tax object is located or on the territory of the district / city concerned and enhanced mobility is quite low and only serving the people in the district / city concerned;

- Object and bases are not contrary to the public interest;

- Object tax is not a tax object or objects provincial and central taxes;

- The potential is adequate;

- Does not give a negative economic impact;

- The aspect of fairness and the ability of the community;

- Protecting the environment. ${ }^{9}$

The role of the officer is no less important to the success of the tax is a close relationship with the community in the payment of taxes. Tax officials are agents of change who became a liaison between the community as a taxpayer with the government. For the smooth implementation of this tax payment, various efforts were made by the interaction giving rise to the perception of the tax payment for the smooth payment of taxes. In other words, they attempt to socialize or to make tax counseling, aiming to persuade the general public Brebes. With hope will one day emerge a positive perception of society towards the tax itself. One method used is to inform about the importance of paying taxes and benefits that will be felt at the same time the public directly or indirectly with the payment of the tax. More details about

\footnotetext{
${ }^{9}$ Ibid, hlm.2.
} 
the role of tax officials relation to the onset of taxpayer awareness illustrated in the following figure:

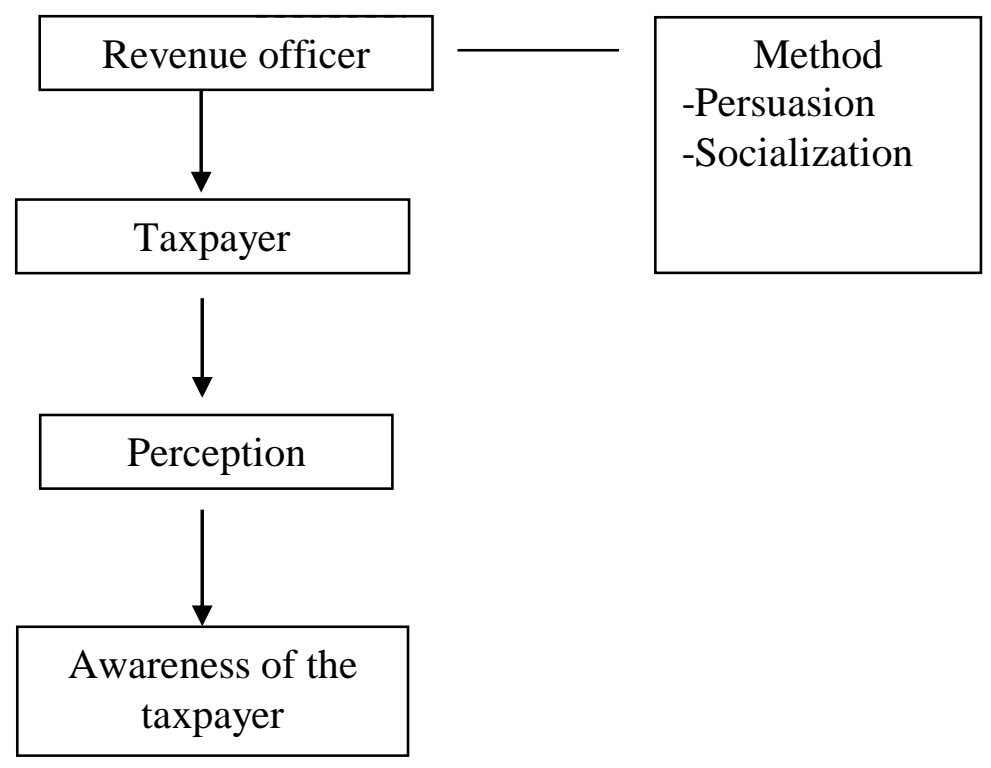

Figure 1. The relationship between tax officials with the taxpayer

From the picture above is known that information plays a not simple, the level of information on the subject (tax officials) to the tax payers are not granted. It can be analyzed by Kelley in theory his opinion about the level of information (information level) is that the level of information concerning one's knowledge of reality with its surroundings. That level of information is the basis for analyzing the person's dependency information from the person. This suggests that the tax officials to obtain information also depends on knowledge. This condition affects about knowledge taxpayer where the taxpayer information obtained will depend on the tax officials themselves. The need for knowledge of the clerk so that success can be achieved with good payment then the increase in the learning process and knowledge enhanced officer.

Basically the smoothness and success of the tax is determined by the community itself. But the role of tax officials continue to have its own portion of the taxpayer. In order to maximize the effect of officers should be increased awareness of the officer and his responsibility for the implementation of the tax payment.

Development inhibiting factors such as lack of funding should be used by tax officials in conducting counseling importance of paying taxes. Starting point should be to start melting of the public discourse about development, which is the next stage will bring the people to the concern for the development of the surrounding area. Here is a new perception of stimuli taxman results can be achieved. Perception which would bring the community yourself with and mengaetahui the importance of paying taxes, and also determine the allocation of funds in the taxes they pay to the development participation. In sum tax is of, by and for the community. 
Basically, people do not feel burdened with paying taxes because they are aware of the tax should be paid. This can be seen as a gesture that shows their effort to execute the obligation to set up funds to pay taxes either on time or else not. This condition is supported also by the human personality itself in the act and behave. Services had been there only went back again on the man himself in understanding and awareness of paying taxes directly. This proves that the relationship between tax officials and the perception of the role of taxpayers to pay taxes consciousness are interrelated. Hence the need for cooperation between tax officials and taxpayers can foster a better awareness for the continuing development of this area. The above process is supported by extending the system in the form of tax counseling in an integrated, coordinated by the UN education in every district. The following narrative tax collector clerk:

To raise awareness of the tax compliance has indeed been carried out in formal and informal forums. For formal education is still followed in the United Nations carried out by a team of district government and in collaboration with a team of collectors. As for informal counseling was done at the time of the data collection and several tax management process that went directly to the taxpayer.

The above process is a preventive process, however, when people still stubborn then repressive measures must be enforced, as well as a learning tool for society as a whole. In case the taxpayer fails in performing its obligation to pay taxes, then the county government issued tax assessments. This letter was issued because of two factors: first, if the tax return obligations are not met on time and had been reprimanded in writing nor delivered in time referred dala letter of reprimand, second, if the filling SPT does not correspond to the actual data. Similarly, if the taxpayer fails in performing tax payment then within 3 years after the time the tax becomes due or expiration of the tax, district officials may issue Additional Tax Assessment Letter, if based on the results of the examination or other information turned out to be the amount of tax payable is less or not paid. Tax assessment is coupled with an additional tax of $50 \%$ of the principal taxes.

The existing rules and is valid until today to provide a stimulus so that the community is aware of the tax paying their fines. Late payments subject to administrative sanctions in the form of interest rate of $2 \%$ per month within 24 months calculated from the due date. Insurers are liable tax paid tax that has been collected to the local treasury or through special treasurer receiver or other designated place.

The above conditions is to focus on each of the subjects, namely personnel and taxpayers. Both are very possible to do a 'compromise'. It is widely experienced by the type of hotel and restaurant tax, bird nests, excavation class $C$, because the owner itself serves as a tax collector. in these conditions arise difficulties in determining the tax collector payments to the Government of Regency / City, because the local government does not have effective control tools that can monitor any tax payments made by consumers. In this case the possible manipulation by the tax collector. means taxes paid do not correspond to the tax levied. Similarly, in determining the notice of tax payable for the tax collector (taxpayers) can occur peaceful setting (collusion) between officials who determine taxes payable and the tax collectors (the owner), so that it can hurt the government. In determining the value and the tax levy is not 
difficult even though in terms of hotel and restaurant business, bird nests, class $C$ and other excavation did not issue receipts, end the tax value can be set via the 'negotiations' which means opportunities for irregularities occurring. Collusion between the tax collector with tax officials is the case, because the control mechanisms are still weak, so that officials who colluded difficult.

Other tips are carried out in order to cultivate awareness and public participation is the policy of reward (reward). The shape of the award in question is in the form of granting of a charter to the taxpayer who obey pay taxes regularly and on time. Given the limited budget, until recently Award plaque done proportionally, meaning that not all taxpayers get the award in question but there are certain considerations. One consideration is the amount of tax payments a significant contribution.

Efforts to increase tax revenue is not only done in the framework of the intensification of the system, but also includes extending the system. In an effort extending many things that need to be fixed and evaluated, including:

- Conditions changed the taxpayer every year, because it required the actual data for the taxpayer in each period. The data collection process is done in collaboration with a team of collectors at the district level and also through tax forms filled out by the taxpayer;

- Efforts ekstensfikasi juga done by developing a tax location especially for public areas, and this applies to the advertising tax. Additionally observations of the object of taxation is also being conducted in every period, in order to see the addition or reduction of tax payers in one particular area. This kind of data collection would be useful to estimate the target to be set in the coming period.

- Without awareness, the increased revenue from taxes are sucking jempol alone. Therefore each regency / city continues its efforts to enhance awareness of the taxpayer in paying local taxes. This work is done in three basic ways, first with the importance of paying tax counseling conducted by a team of tax, and performed at the level of districts. The second effort is to apply sanctions in the form of interest charges on taxpayers who are negligent in paying taxes. The last resort is to provide rewards in the form of a charter on taxpayers who have fulfilled certain criteria, and one of them is always paid taxes on time.

\section{Closing}

\subsection{Conclusion}

To manage this tax sector there are some aspects that concern:

- Among the changes in order to improve tax management is to do SOP on the umbrella agency for financial management and more specifically the tax sector.

- To streamline the tax administration, some of the steps taken, among others, in addition to institutional changes also include improvements in the quality of human resources, with more technical personnel engage in structural and functional training.

- To provide convenience to the taxpayer in the care of mainly tax payment, the payment counter cultivated close as possible to the location of taxes. 
- Make improvements to the tax system, some of these efforts are to conduct periodic checks on the tax object and also went to taxpayers who are found to violate the rules, and to set strict sanctions.

\subsection{Suggestion}

Based on the analysis and the conclusion it could be said a few suggestions as follows:

- The need for rigor in the implementation of tax legislation. If komprpomi factor is still done by the tax collector and the taxpayer preformance proes tax collection, the tax revenue will not be maximized.

- To overcome indecision tax collectors need for evaluation or training to improve human resources, especially in the field. If the tax collector clerk does not work according to SOP hence the need for sanctions to the person concerned.

- For the people or objects taxes should pay taxes on time, because if the tax revenue has reached its target then the tax revenue is expected to support the development, especially in the regency / municipality.

\section{Bibliography}

[1] Halim, Abdul, 20014, Manajemen Keuangan Daerah, Edisi Revisi UPP AMP YKPN, Yogyakarta.

[2] Hoogerwef, A., 1983, Ilmu Pemerintahan, Erlangga, Jakarta.

[3] Mardiasmo, 2002, Otonomi dan Manajemen Keuangan Daerah, Penerbit ANDI, Yogyakarta.

[4] Widjaja, HAW, 2009, Otonomi Daerah dan Daerah Otonom, Divisi Buku Perguruan Tinggi, PT. Grafindo Persada. Rajawali Pers. Jakarta

[5] Yani, Ahmad, 2008, Hubungan Keuangan antara Pemerintah Pusat dan Daerah di Indonesia, PT. Raja Grafindo Persada, Jakarta. 